\title{
Diversity of Coleoptera in Maize Crops (Zea mays L.) and a Secondary Succession Area in Paraíba, Brazil
}

\author{
Angélica da Silva Salustino ${ }^{1}$, Maria Ítala Alves de Souza ${ }^{1}$, Ana Jéssica Soares Barbosa ${ }^{1}$, \\ Josefa Jussara Rêgo Silva ${ }^{1}$, Valdemir Ribeiro Cavalcante Silva ${ }^{1}$, Fabio Mielezrski ${ }^{1}$, Gleidyane Novais Lopes ${ }^{1}$ \\ \& Carlos Henrrique de Brito ${ }^{1}$ \\ ${ }^{1}$ Departamento de Fitotecnia e Ciências Ambientais, Universidade Federal da Paraíba, Campus II, Areia, \\ Paraíba, Brazil \\ Correspondence: Angélica da Silva Salustino, Departamento de Fitotecnia e Ciências Ambientais, Universidade \\ Federal da Paraíba, Campus II, Areia, Paraíba, Brazil. Tel: 55-83-9815-3945. E-mail: \\ angelicasalustino@gmail.com
}

\author{
Received: April 24, $2019 \quad$ Accepted: May 31, $2019 \quad$ Online Published: July 15, 2019 \\ doi:10.5539/jas.v11n10p322 URL: https://doi.org/10.5539/jas.v11n10p322
}

\begin{abstract}
This work compares the diversity of beetles (Coleoptera) in areas of maize cultivation with fertilization (NPK) and without fertilization, and a field in secondary succession (capoeira) aiming to understand the relation of these organisms in the different systems. The study was carried out in a farm belonging to EMEPA-PB, in the city of Alagoinha, Paraíba state, Brazil, from July to August 2018. Insects were captured in Provid traps and collected every seven days during the vegetative period of the crop. The screenings were carried out at the Zoology Laboratory of the Universidade Federal da Paraiba and the specimens identified at the family level. Data were analyzed using the ANAFAU program. Ten families of beetles were found: Alleculidae, Cecindelidae, Coccinellidae, Carabidae, Scarabaeidae, Cleridae, Staphylinidae, Erotylidae, Chrysomelidae, and Tenebrionidae. Five families were common in all studied areas except for Staphylinidae that was absent in the fertilized area. Beetle families classified as predatory insects were more abundant in the non-fertilized maize system and secondary succession area, except the Coccinellidae family. The families considered as maize crop pests (Scarabaeidae, Chrysomelidae, and Tenebrionidae) had higher abundance in the fertilized maize system. The Erotylidae family also showed predominance in the non-fertilized area. We conclude that there is a greater diversity of beetle in the non-fertilized maize crop when compared to the other studied areas.
\end{abstract}

Keywords: faunal survey, biodiversity, arthropods, fertilization

\section{Introduction}

Maize [Zea mays L. (Poaceae)] is one of the most cultivated and consumed cereals worldwide due to its extensive use as human and animal food and for industrial purposes. Brazil is the world second largest exporter of maize, with most production occurring in the southern and center-western regions (CONAB, 2017; Fancelli et al., 2015). In northeastern Brazil, maize also has significant socioeconomic importance, since several small producers depend on this crop and do not have technical management inputs (Cruz \& Pereira, 2002).

Maize cultivation requires some nutrients, for example, nitrogen (Nakao et al., 2014), so the management of soil and fertilization are essential for the good development of the crop. There is a great variety of organisms present in the soil which have varied functions and many sizes and metabolic forms (Oliveira et al., 2009). The presence of organisms promotes proper functioning of life cycles in soil, becoming primordial in the development and maintenance of the cultures (Mendes et al., 2009). These organisms protect the organic matter from mineralization caused by the mechanical action in soil, besides favoring the mobility of nutrients (Silva \& Salvadori, 2004; Sánchez \& Reinés, 2001).

However, the fragmentation of forests to establish productive activities, such as agriculture, mining, and livestock, comprises one a leading factor causing loss of biodiversity (Newbold et al., 2015). Thus, some groups of insects tend to disappear or even to be replaced by opportunistic organisms, causing disturbances in the agricultural systems (Gullan \& Cranston, 2008). 
The Coleoptera order comprises the largest group of Insecta class, whose representatives are strictly related to the soil (Begha et al., 2018; Triplehorn \& Johnson, 2011). The beetles stand out as a vital group from the economic and ecological point of view because some species act as pests, other as natural enemies, pollinators and even decomposers of organic matter (Nichols et al., 2011; Lima et al., 2013; Costa et al., 2014). Some species of beetles are herbivorous, feeding on several crops, thus causing economic damages to the farmers. On the other hand, they may benefit crops by recycling nutrients and contributing to the biological control of weeds and pest insects (Begha et al., 2018; Casari et al., 2012).

Therefore, the investigation of the benefits provided by invertebrates is a fundamental tool for understanding the dynamics of agricultural production. Because insects have many functions in the environment, it is essential to characterize them. Therefore, the knowledge about Coleoptera species affecting local crops is a way of understanding their impact on agriculture and indicating correct management practices for cropping. In this perspective, this survey aimed to characterize the diversity of beetles in areas of fertilized maize crops (NPK) and areas without fertilization, as well as to understand the relation of these organisms in the different systems.

\section{Method}

The survey was carried out at the State Agricultural Research Company of Paraíba (Empresa Estadual de Pesquisa Agropecuária da Paraíba; EMEPA-PB), in Alagoinha city (06 $57^{\prime} 00^{\prime \prime} \mathrm{S}, 35^{\circ} 32^{\prime} 42^{\prime \prime} \mathrm{W}$; $133 \mathrm{~m}$ ), in the meso-region of Agreste, Paraiba, Brazil, from July to August 2018. According to Köppen classification, the local climate is As' (Brazil, 1972), characterized as humid with autumn-winter rains (EMBRAPA, 1999). The captures of insects occurred at the end of the rainy season between July and August, with rainfall averaging $26.05 \mathrm{~mm}$ and temperatures ranging from 22 to $26^{\circ} \mathrm{C}$ (AESA, 2018).

The experiment was carried out in three areas, being two maize cultivation areas with and without fertilization (NPK addition) and one of secondary succession called capoeira. The maize areas were prepared with mechanical traction (one plowing and two harrowings). The maize cultivar was 'Ipanema'. In both crops, we used a four-row sowing machine with a spacing of $0.80 \mathrm{~m} \times 0.20 \mathrm{~m}$, with a population of 62,500 plants $/ \mathrm{ha}$. The fertilization was carried out based on the soil analysis, with the application of $80 \mathrm{~kg}$ of nitrogen in the urea form, $60 \mathrm{~kg}$ of simple superphosphate, and $40 \mathrm{~kg}$ of potassium in the form of potassium chloride. The non-fertilized area received no crop protection after sowing.

Five Provid-type traps were set up in each area. The traps were made with pet bottles (2 L), with dimensions of 4 $\times 4 \mathrm{~cm}$ and height of $15 \mathrm{~cm}$ from the base to the holes. In the field, the traps were installed in the central lines of each area spaced at 2.5 meters and buried in the ground so that the edges were at the level of surface facilitating the entrance of insects. Inside each trap, we added a solution composed of $20 \mathrm{ml}$ of $70 \%$ alcohol, $30 \mathrm{ml}$ of neutral detergent, $25 \mathrm{ml}$ of water, and five drops of formaldehyde to preserve the captured specimens. The traps were inspected weekly.

The collected material was sent to the laboratory of Invertebrate Zoology in the Biological Sciences Department of the Federal University of Paraíba (UFPB-Campus II), where the triages were carried out, and specimens counted and identified at the family level. Identification was carried out using a stereoscopic microscope and identification keys.

The data were analyzed with the ANAFAU program (Moraes et al., 2003). We calculated the indexes of dominance, abundance, frequency, and constancy.

\section{Results and Discussion}

The traps collected a total of 263 Coleoptera specimens, with representatives of 10 families from two cropping systems in the maize crop (maize fertilized with NPK and maize without fertilizer sources) and a secondary succession area.

In the fertilized maize crop, 100 individuals were captured, comprising nine families: Alleculidae, Cecindelidae, Coccinellidae, Carabidae, Scarabaeidae, Cleridae, Erotylidae, Chrysomelidae, Tenebrionidae. The predominant families (*) were Scarabaeidae and Tenebrionidae, which had the highest faunal indexes as dominant, very abundant, very frequent, and constant, making up a total of $61 \%$ of the identified arthropods (Table 1). 
Table 1. Faunal analysis of Coleoptera collected in maize crop fertilized with NPK

\begin{tabular}{lllllll}
\hline Family & Individuals & $\mathbf{\%}$ & D & A & F & C \\
\hline Alleculidae & 11 & 11 & d & c & f & w \\
Cecindelidae & 7 & 7 & d & c & f & w \\
Coccinellidae & 3 & 3 & nd & d & if & y \\
Carabidae & 3 & 3 & nd & d & if & w \\
* Scarabaeidae & 34 & 34 & d & va & vf & w \\
Cleridae & 1 & 1 & nd & d & if & y \\
Erotylidae & 12 & 12 & d & c & f & w \\
Chrysomelidae & 2 & 2 & nd & d & if & y \\
$*$ Tenebrionidae & 27 & 27 & d & va & vf & w \\
- Total & 100 & 100 & & & &
\end{tabular}

Note. $\mathrm{D}=$ Dominance: $\mathrm{d}=$ dominant; $\mathrm{nd}=$ non-dominant. $\mathrm{A}=$ Abundance: $\mathrm{va}=$ very abundant; $\mathrm{c}=$ common and $\mathrm{d}=$ dispersed. $\mathrm{F}=$ Frequency: $\mathrm{vf}=$ very frequent; $\mathrm{f}=$ frequent and if $=$ infrequent. $\mathrm{C}=$ Constancy: $\mathrm{w}=$ constant; $\mathrm{y}=$ accessory. ${ }^{*}$ Predominant Family.

In the area of maize cultivation without fertilization, 120 beetles were collected, comprising ten families: Alleculidae, Cecindelidae, Coccinellidae, Carabidae, Scarabaeidae, Cleridae, Staphylinidae, Erotylidae, Chrysomelidae, Tenebrionidae. Among these, the Scarabaeidae and Erotylidae families were predominant, accounting for $60.9 \%$ of the collected insects (Table 2).

Table 2. Faunal analysis of Coleoptera collected in non-fertilized maize crop

\begin{tabular}{lllllll}
\hline Family & Individuals & $\mathbf{\%}$ & D & A & F & C \\
\hline Alleculidae & 5 & 4.2 & nd & c & f & w \\
Cecindelidae & 16 & 13.3 & d & c & f & w \\
Coccinellidae & 3 & 2.5 & nd & c & f & y \\
Carabidae & 5 & 4.2 & nd & c & f & w \\
$*$ Scarabaeidae & 26 & 21.7 & d & va & vf & w \\
Cleridae & 3 & 2.5 & nd & c & F & y \\
Staphylinidae & 2 & 1.6 & nd & d & if & y \\
*Erotylidae & 47 & 39.2 & d & va & vf & w \\
Chrysomelidae & 2 & 1.6 & nd & d & if & w \\
Tenebrionidae & 11 & 9.2 & d & c & f & w \\
Total & 120 & 100 & & & &
\end{tabular}

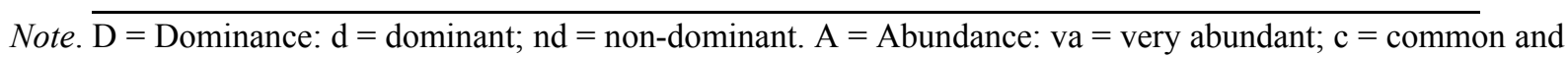
$\mathrm{d}=$ dispersed. $\mathrm{F}=$ Frequency: $\mathrm{vf}=$ very frequent; $\mathrm{f}=$ frequent and if $=$ infrequent. $\mathrm{C}=$ Constancy: $\mathrm{w}=$ constant; $\mathrm{y}=$ accessory. $*$ Predominant Family.

In the second succession area, 43 beetles were collected, consisting of five families: Coccinellidae, Carabidae, Scarabaeidae, Staphylinidae, Tenebrionidae. The Scarabaeidae family was predominant, which accounted for $46.5 \%$ of the specimens (Table 3 ). 
Table 3. Analise faunística de coleópteros coletados em área de capoeira

\begin{tabular}{lllllll}
\hline Family & Individuals & $\mathbf{\%}$ & D & A & F & C \\
\hline Coccinellidae & 2 & 4.6 & nd & d & if & y \\
Carabidae & 4 & 9.3 & nd & c & f & w \\
$*$ Scarabaeidae & 20 & 46.5 & d & va & vf & w \\
Staphylinidae & 7 & 16.3 & d & c & f & w \\
Tenebrionidae & 10 & 23.3 & d & c & f & w \\
\hline Total & 43 & 100 & & & &
\end{tabular}

Note. $\mathrm{D}=$ Dominance: $\mathrm{d}=$ dominant; $\mathrm{nd}=$ non-dominant. $\mathrm{A}=$ Abundance: $\mathrm{va}=$ very abundant; $\mathrm{c}=$ common and $\mathrm{d}=$ dispersed. $\mathrm{F}=$ Frequency: $\mathrm{vf}=$ very frequent; $\mathrm{f}=$ frequent and if $=$ infrequent. $\mathrm{C}=$ Constancy: $\mathrm{w}=$ constant; $\mathrm{y}=$ accessory. $*$ Predominant Family.

The families found in our survey are commonly found in entomological studies on Coleoptera in different environments including agricultural areas.

The Scarabaeidae family (scarabs) was predominant in this study. Some species have tight association with maize crop, among them Cyclocephala flavipennis, Diloboderus abderus, Dyscinetus dubius, Euetheola humilis, Liogenys sp., Phyllophaga triticophaga, and Stenocrates sp., whose larvae are pests of great importance since they feed on the root system, causing severe damages to the crop (Rodrigues et al., 2011; Cunha et al., 2007).

The species Diloboderus abderus Sturm (Coleoptera: Scarabaeidae) damages wheat crops because its larvae consume the seeds and the root system in a depth that varies between 10 and $30 \mathrm{~cm}$ from the ground, weakening or even kill the plants (Valle et al., 2017). Some species of Liogenys Guerin-Meneville, 1831 cause damage to soybean and maize crops, occurring in many Brazilian states (Cherman et al., 2011).

However, scarabs are also vital for ecosystems, contributing to nutrient cycling and soil quality. Dung beetles, for example, feed on feces and dead animals. In this way, these insects perform an ecological service by removing excrement and incorporating them in the soil through the excavation of tunnels (Nichols et al., 2008; Almeida \& Louzada, 2009; Salomão et al., 2017).

The second most abundant family, Tenebrionidae, comprises common inhabitants of different arid and semi-arid environments around the world (Santos et al., 2002; Bartholomew \& Moghrabi, 2018). Larvae and adults are mainly associated with two types of habitat, the soil and trees. In arid regions, they show an important ecological role as detritivores and as a source of food for several vertebrates (Crawford, 1981; Ruiz \& Caballero, 2014). Tenebrionids feed on decomposing plant or animal matter, while some larvae inhabit the soil feeding on roots and seeds (Gonçalves, 2017). The Lagria villosa species, a Tenebrionidae, is widely distributed in Brazil, mainly in areas of crops, such as maize, beans, and soybean (Macari, 2013).

The second most abundant family in non-fertilized maize was Erotylity, which is a medium-sized family with approximately 3200 species distributed worldwide (Grzynowicz, 2002). Due to its mycophagous habit, larvae and adults feed on fungal bodies and adults are often found in places where these microorganisms are present (Gallo et al., 2002).

In the Chrysomelidae family, most species are herbivorous, feeding on various parts of the plant such as roots, stems, leaves, and fruits. Some species of this family are pests of agricultural importance, while others stand out as potential agents in the biological control of weeds (Jolivet et al., 2002).

Diabrotica speciosa (Germar) (Chrysomelidae), the Cucurbit Beetle, is an economically important pest in several cultures of the Neotropical region, representing quarantine risks in Nearctic and Palearctic areas (Nardi et al., 2012). In Brazil, the number of resources spent to control D. speciosa and its economic impact on agriculture are still unknown. However, there is a significant amount of active ingredients applied annually to control this pest, both in adult and larval stages, especially in crops such as maize, beans, and potatoes in the southeastern and southern regions of the country (Ávila et al., 2011).

Many species of Carabidae, Coccinellidae, Cecindelidae, Claridae, and Staphylinidae have great economic importance and deserve studies on pest management. They may be kept in agricultural systems to contribute as biological controls, acting as natural enemies of other arthropods including pests and insect populations (Cividanes et al., 2009; Triplehorn \& Johnson, 2011; Rifkind, 2012; Vidotto et al., 2018). 
Carabidae and Staphylinidae are predator insects inhabiting soils. Among the prey of Carabidae are ants, aphids, caterpillars, insect eggs, springtails, and mites, while small Staphylinidae species feed on nematodes, mites, and springtails (Ekschmitt et al., 1997). According to Cividanes et al. (2014), some species of Carabidae and Staphylinidae beetles have a high predatory potential on the fourth instar of the velvetbean caterpillar, Anticarsia gemmatalis (Hübner), in the laboratory, causing mortality rate greater than or equal to $80 \%$. Some species of Carabidae are notable for their predominance in maize and soybean cultivars such as Scarites sp.1, Abaris basistriata, Odontocheila nodicornis, Calosoma granulatum, and Loxandrus sp.1, being dominant in agroecosystems (Martins et al., 2013).

There is no information about damages or benefits of the Alleculidae family on maize culture, but they are essential arthropods to maintain the balance of ecosystems.

Comparing the occurrence of Coleoptera in maize cultivations with and without fertilization and the secondary succession area, we verified that the families classified as predatory insects were more abundance in non-fertilized maize and the secondary succession, except the family Coccinellidae that had higher abundance in the areas of fertilized maize and secondary succession. The maize crop pests (Scarabaeidae, Chrysomelidae, Tenebrionidae) showed higher abundance in the maize system with fertilization of NPK and in the capoeira area, except for the Chrysomelidae family, which was absent in the secondary succession area. The Erotylidae family also showed predominance in the non-fertilized area (Figure 1).

\section{Relationship of beetle (Coleoptera) occurrence in maize} and a secondary succession area

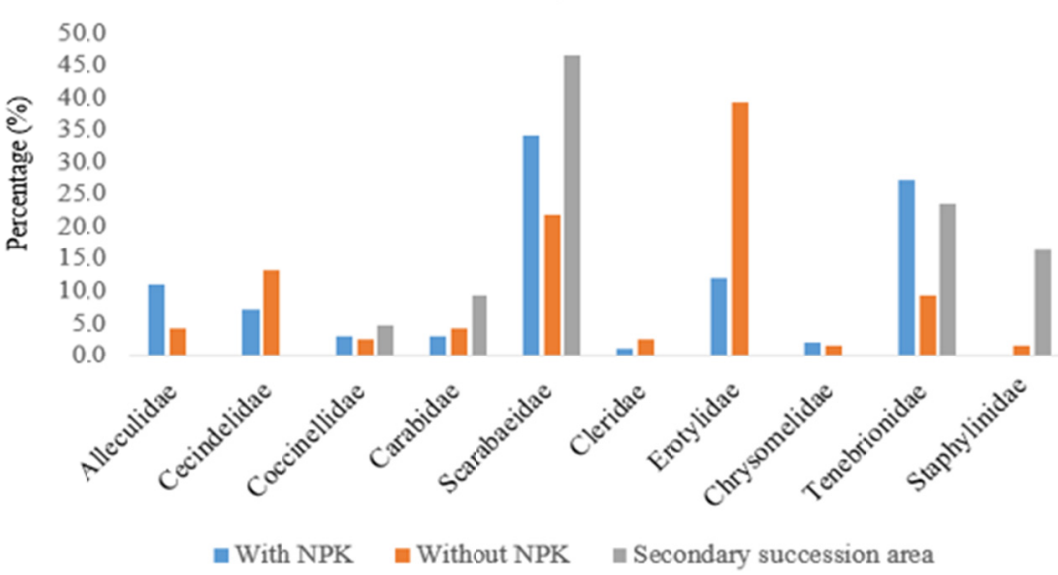

Figure 1. Relationship of beetle (Coleoptera) occurrence in maize crop systems with and without fertilization using NPK and a secondary succession area

According to Martins et al. (2013), no-till cultivation areas with large forest fragments show a greater diversity of Carabidae and Staphylinidae species when compared to areas with conventional preparation of soil. This fact corroborates our results because since both families were more abundant in the cultivation of non-fertilized maize and without crop protection after planting as well as in the area of secondary succession.

The diversity of Coleoptera in the soil may be related to the availability of organic matter and the diversification of plants in the area, which are critical pieces for the maintenance of soil temperature and humidity (Boscardin et al., 2017). The high level of organic matter may explain the diversity of beetles in the area of non-fertilized maize (Silva \& Carvalho, 2000; Nunes et al., 2009).

The predominance of Erotylidae in the area of non-fertilized maize may be related to the local moisture since the vegetal cover favored the development of fungi, the primary food source of these insects.

The pest predominance found in fertilized maize may reflect a prediction of the "Trofobiose" theory (Chaboussou, 2006), which states that improperly managed soil fertilization can cause a nutritional imbalance in the plant, making it more or less susceptible to attack by insect pests.

Another hypothesis for the emergence of pests would be the possibility of insects fed with fertilized plants being better nourished and consequently more resistant. According to Roel et al. (2017), pupae resulting from 
caterpillars fed with chemically fertilized maize leaves are heavier than those with organically fertilized leaves, which reflects in the viability of adults.

On the other hand, some insects associated with green manures and different types of natural coverages can harm crops. Since the fauna of the soil relates to the kind of interaction between invertebrates and microorganisms, the digestion of compounds and manure contributes to the structural formation of the soil (Correia, 2005).

The small number of beetles in the secondary succession area may be related to the deforestation process, which causes reduction of habitats and consequently reduction of species, favoring imbalances in the food chains and increasing the incidence of pests (Salati et al., 2006).

Collection work and inventories of Coleoptera are necessary since research on this subject is still incipient. As a result of environmental changes, agricultural systems need monitoring for proper distribution of beetle species.

\section{References}

AESA. (2018). Executive Agency for Water Management of the State of Paraíba. Metereologia. Recovered from http://www.aesa.pb.gov.br/aesa-website

Almeida, S. S. P., \& Louzada, J. N. C. (2009). Community structure of Scarabaeinae (Scarabaeidae: Coleoptera) in brazilian savannah phytophysiognomies and its importance for conservation. Neotropical Entomology, 38(1), 32-43. https://doi.org/10.1590/S1519-566X2009000100003

Avila, C. J., \& Santana, A. G. (2011). Larva-pin. In P. A. Viana (Ed.), Principal corn pest plagues in Brazil (pp. 21-31). Embrapa Maize and Sorghum, Brazil. Retrieved from https://ainfo.cnptia.embrapa.br/digital/ bitstream/item/56174/1/doc-129.pdf

Bartholomew, A., \& Moghrabi, J. E. (2018). Seasonal preference of darkling beetles (Tenebrionidae) for shrub vegetation due to high temperatures, not predation or food availability. Journal of Arid Environments, 156, 34-40. https://doi.org/10.1016/j.jaridenv.2018.04.008

Begha, B. P., Antunes, C. H., \& Milléo, J. (2018). Coleopterofauna (Insecta: Coleoptera) collected in traps with essential oil of citronella or its components in the city of Ponta Grossa, Paraná, Brazil. Entomo Brasilis, 11(2), 78-84. https://doi:10.12741/ebrasilis.v11i2.734

Boscardin, J., Costa, E. C., Paulus, E., Machado, D. N., Pedron, L., \& Silva, P. G. (2017). Pecan growth under different soil preparation and hole sizes: Coleopterans as bioindicators. Pesquisa Florestal Brasileira, 37(92), 587-596. https://doi.org/10.4336/2017.pfb.37.92.1496

Brazil, Ministry of Agriculture. (1972). Exploratory Survey of Soils of the State of Paraíba. Interpretation for Agricultural Use of Soils of the State of Paraiba (pp. 2-647). Rio de Janeiro, Brazil. Retrieved from http://library.wur.nl/isric/fulltext/isricu_i00003046_001.pdf

Casari, S. A., \& Ide, S. (2012). Coleoptera. In J. A. Rafael, G. A. R. Melo, C. J. B. Carvalho, S. Casari, \& R. Constantino (Eds.), Insects of Brazil: Diversity and Taxonomy (pp. 453-535). Holos, Ribeirão Preto.

Cherman, M. A., Guedes, J. V. C., Morón, M. A., Prá, E. D., Perini, C. R., \& Jung, A. H. (2011). First record of species of Liogenys (Coleoptera, Melolonthidae) associated with winter grain crops in Rio Grande do Sul (Brazil). Revista Brasileira de Entomologia, 55(4), 618-620. https://doi.org/10.1590/S0085-562620110 05000052

Cividanes, F. J., Barbosa, J. C., Martins, I. C. F., Pattaro, F., Nunes, M. A., \& Santos, R. S. (2009). Diversity and spatial distribution of ground arthropods in agroecosystems. Bragantia, 68(4), 991-1002. https://doi.org/ $10.1590 / \mathrm{S} 0006-87052009000400020$

Cividanes, F. J., Ide, S., Ribeiro, A. A., Cividanes, T. M. S. (2014). Predatory potential of Carabidae and Staphylinidae (Coleoptera) on velvetbean caterpillar. Pesquisa Agropecuária Brasileira, 49(8), 652-655. https://doi.org/10.1590/S0100-204X2014000800010

CONAB. (2017). Monitoring of Brazilian Grain Harvest (Vol. 4, No. 11, pp. 1-171). National Supply Company, Brazil. Retrieved from https://www.conab.gov.br/info-agro/safras/graos/boletim-da-safra-de-graos

Correia, M. E. F., \& Oliveira, L. C. M. (2005). Importance of soil fauna for the cycling of nutrients. In A. M. Aquino, \& R. L. Assis (Eds.), Biological processes in the soil-plant system: Tools for sustainable agriculture (pp. 77-99). Embrapa Agrobiologia, Brasília, DF. 
Costa, E. M., Araújo, E. L., Silva, F. E. L., Nogueira, C. H. F., \& Silva, P. A. F. (2014). Diversity of Coleoptera in cultivated area with watermelon in the semi-arid region of Rio Grande do Norte. Agroambiente Online Magazine, 8(2), 293-297. https://doi.org/10.18227/1982-8470ragro.v8i2.2058

Crawford, S. C. (1981). Biology of Desert Invertebrates (1st ed.). Springer Verlag, New York. https://doi.org/ 10.1007/978-3-642-85794-2

Cruz, J. C., \& Pereira, F. A. (2002). Management and cultural practices for the cultivation of green corn. Technical Circular (No. 16, pp. 1-9). Embrapa, Brazil. Retrieved from https:/ainfo.cnptia.embrapa.br/ digital/bitstream/CNPMS/13777/1/Circ_16.pdf

Cunha, U. S., Grützmacher, A. D., Martins, J. F. S., Stefanello, Jr. G. J., \& Jardim, E. O. (2007). Occurrence of Euphoria lurida (Fabricius) (Coleoptera: Scarabaeidae) in the corn cultivated in Lowland at Rio Grande do Sul State. Neotropical Entomology, 36(6), 976-979. https://doi.org/10.1590/S1519-566X2007000600023

Ekschmitt, K., Weber, M., \& Wolters, V. (1997). Spiders carabids, and staphylinids: The ecological potential of predatory macroarthropods. In G. Benckiser (Ed.), Fauna in Soil Ecosystems: Recycling Processes, Nutrient Fluxes, and Agricultural Production (pp. 309-348). Books in Soils, Plants, and the Environment.

Embrapa. (1999). Brazilian system of soil classification. Brasilia, Information Production. Rio de Janeiro, Brazil: Embrapa Solos. Retrieved from https://www.agrolink.com.br/downloads/sistema-brasileiro-de-classifica cao-dos-solos2006.pdf

Fancelli, A. L., Alves, L. R., \& Almeida, R. E. M. (2015). The maize productive chain. Agricultural view-School of Agriculture Luiz de Queiroz, 13(9), 1-170.

Gallo, D., Nakano, O., Neto, S. S., Carvalho, R. P., Baptista, G. C., \& Filho, E. B. (2002). Agricultural entomology. Piracicaba: Fealq.

Gonçalves, M. P. G. (2017). Relationship Between Meteorological Conditions and Beetles in Mata de Cocal. Revista Brasileira de Meteorologia, 32(4), 543-554. https://doi.org/10.1590/0102-7786324003

Grzynowicz, W. P. (2002) Morphology, phylogeny and classification of the erotylidae family based on adult characters (Coleoptera: Cucujoidea). Genre, 13(2), 435-504

Gullan, P. J., \& Cranston, P. S. (2007). Insects: A summary of entomology (3rd ed.). São Paulo, Roca.

Jolivet, P. H., \& Verma, K. K. (2002). Biology of leaf beetles. Intercept Ltd. Andover.

Lima, M. G. A., Silva, R. P. A., Sousa M. D. F., \& Costa, E. M. (2013). Diversity of Scarabaeinae (Coleoptera: Scarabaeidae) in the Ceará Botanical Park, Caucaia-CE, Brazil. Revista Agro@mbiente On-line, 7(1), 89-94. https://doi.org/10.18227/1982-8470ragro.v7i1.970

Macari, B. P. (2013). Arqueoentomology: A case study from Tupiguarani, Altônia, Paraná, Brazil (Masters dissertation, Federal University of Paraná, Paraná).

Martins, I. C. F., Cividanes, F. J., Ide, S., \& Haddad, G. Q. (2013). Diversity and habitat preferences of Carabidae and Staphylinidae (Coleoptera) in two agroecosystems. Bragantia, 71(4), 471-480.

Mendes, L. C., Hungary, M., Junior, F. B. R. Fernandes, M. F., Chaer, G. M., Mercante, F. M., \& Zilli, J. E. (2009). Bioindicators for Tropical Soil Quality Assessment: Utopia or Reality? Embrapa, Brazil. Retrieved from https://ainfo.cnptia.embrapa.br/digital/bitstream/CPAC-2010/31300/1/doc-246.pdf

Moraes, R. C. B., Haddad, M. L., Silveira Neto, S., \& Reyes, A. E. (2003). Software for statistical analysis-ANAFAU. Symposium of Biological Control, 8, São Pedro, SP. Abstracts. Piracicaba: ESALQ/USP. Retrieved from http:/www.lea.esalq.usp.br/softwares

Nakao, A. H., Dickmann, L., Souza, M. F. P., Rodrigues, R. A., \& Tarsitano, M. A. A. (2014). Economic Analysis of the production of safflower corn in function of sources and doses of nitrogen and foliar inoculation with Azospirillum brasilense. Encyclopedia Biosphere, 10(18), 278-290.

Nardi, C., Luvizotto, R. A., Parra, J. R. P., \& Bento, J. M. S. (2012). Mating behavior of Diabrotica speciosa (Coleoptera: Chrysomelidae). Environmental Entomology, 41(3), 562-570. https://doi.org/10.1603/ EN10284

Newbold, T., Hudson, L. N., Hill, S. L. L., Contu, S., Lysenko, I., Senior, R. A., ... Purvis A. (2015). Global effects of land use on local terrestrial biodiversity. Nature, 520(7545), 45-50. 
Nichols, E., Spector, S., Louzada, J., Larsen, T., Amezquita, S., \& Favila, M. E. (2008). Ecological functions and ecosystem services provided by Scarabaeinae dung beetles. Biological Conservation, 141(6), 1461-1474. https://doi.org/10.1016/j.biocon.2008.04.011

Nunes, L. A. P. L., Araújo, J. A., \& Menezes, R. I. Q. (2009). Diversity of edaphic fauna in soils submitted to different management systems in the northeastern semi-arid region. Agrarian Scientia, 10(1), 43-49. https://doi.org/10.5380/rsa.v10i1.13162

Oliveira, E. M., Santos, M. J., \& Souto, J. S. (2009). Fauna of the soil in three environments in the Municipality of Lagoa Seca-PB, 30(1), 33-36.

Jacques, R. (2012). A new species of Cregya LeConte (Coleoptera: Cleridae). Pan-Pacific Entomologist, 88(2), 117-121. https://doi.org/10.3956/0031-0603-88.2.117

Rodrigues, S. R., Carmo, J. I., Oliveira, V. S., Tiago, E. F., \& Taira, T. L. (2011). Occurrence of phytophagous scarabaeidae (Insecta: Coleoptera) larvae in different crop succession systems. Tropical Agriculture Research, 41(1), 87-93. https://doi.org/10.5216/pat.v41i1.7698

Roel, A. R., Soares, J. A. L., Peruca, R. D., Pereira, L. C., \& Jadoski, C. J. (2017). Occurrence in field and development lab Spodoptera frugiperda (J.E. Smith) (Noctuidae) in corn with organic fertilizer and chemical. Brazilian Journal of Applied Technology for Agricultural Science, 10(1), 67-73. https://doi.org/ 10.5935/PAeT.V10.N1.07

Ruiz, C. P., \& Caballero, S. Z. (2014). Biodiversidad de Tenebrionidae (Insecta: Coleoptera) en México. Revista Mexicana de Biodiversidad, 85, 325-331. https://doi.org/10.7550/rmb.31690

Salati, A., Santos, Â. A. dos, \& Klabin, I. (2006). Relevant medical topics. Advanced Studies, 20(56), 107-127. https://doi.org/10.1590/S0103-40142006000100009

Salomão, R. P., Bezerra, B. M., \& Iannuzzi, L. (2017). Daily activity of Dichotomius geminatus (Arrow, 1913) and Deltochilum verruciferum Felsche, 1911 (Coleoptera: Scarabaeinae) facing carrion. Revista Brasileira de Entomologia, 61(4), 300-306. https://doi.org/10.1016/j.rbe.2017.07.001

Sánchez, S., \& Reinés, M. (2012). Role of edaphic macrofauna in livestock ecosystems. Pastures and Forages, 24(3), 191-202.

Santos, A., Nicolas, J., \& Ferrer, F. (2002). Habitat selection and assemblage structure of darkling beetles (Col. Tenebrionidae) along environmental gradients on the island of Tenerife (Canary Islands). Journal of Arid Environments, 52(1), 63-85. https://doi.org/10.1006/jare.2001.0927

Silva, M. T. B., \& Salvadori J. R. (2006). Coró-das-pastagens. In J. R. Salvadori (Ed.), Soil pests in Brazil (pp. 191-210). Passo Fundo: Embrapa Trigo.

Silva, R. A., \& Carvalho, G. S. (2000). Insect ocurrence in corn crop grown under no-tillage collected with pitfall traps. Ciência Rural, 30(2), 199-203. https://doi.org/10.1590/S0103-84782000000200001

Triplehorn, C. A., \& Johnson, N. F. (2011). Estudo dos insetos: Tradução da $7^{a}$ edição de Borror and Delong's introduction to the study of insects. São Paulo, SP: Cengage Learning.

Valle, E. E. D., Frizzo, L. S., Lax, P., Bonora, J. S., Palma, L., Desch, N. P. B., ... Doucet, E. M., (2017). Biological control of Diloboderus abderus (Coleoptera: Scarabaeidae) larvae using Steinernema rarum CUL (Nematoda: Steinernematidae) and Heterorhabditis bacteriophora SMC (Nematoda: Heterorhabditidae). Crop Protection, 98(1), 184-190. https://doi.org/10.1016/j.cropro.2017.04.004

Vidotto, F. L., Vilela, V. L. D., Silva, C. V., \& Schneider, L. C. L. (2018). Entomofauna presente em plantação de milho geneticamente modificado. Revista Terra e Cultura, 30(59), 27-36.

\section{Copyrights}

Copyright for this article is retained by the author(s), with first publication rights granted to the journal.

This is an open-access article distributed under the terms and conditions of the Creative Commons Attribution license (http://creativecommons.org/licenses/by/4.0/). 